\title{
大腿筋膜張筋一腸脛勒带拘縮に対し内視鏡を用いた 腸脛勒带切離術を施行した一例
}

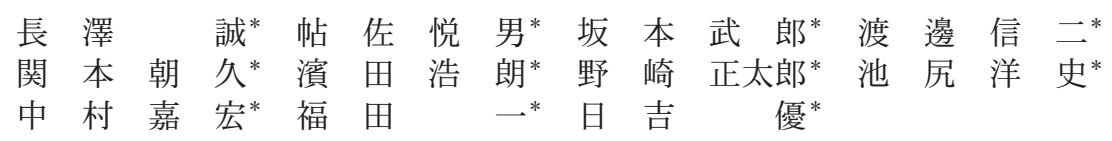

\author{
A Case Report of Endoscopic Iliotibial Band Release \\ for Contracture of Tensor Fasciae \\ Latae Muscle-Iliotibial Band \\ Makoto Nagasawa*, Etsuo Chosa*, Takero Sakamoto*, \\ Shinji Watanabe*, Tomohisa Sekimoto*, Hiroo Hamada*, \\ Shotaro Nozaki*, Hiroshi Ikejiri*, Yoshihiro Nakamura*, \\ Hajime Fukuda*, and Masaru Hiyoshi*
}

今回，大腿筋膜張筋一腸脛靭帯拘縮に対し内視鏡を用いた腸脛勒帯切離術を施行した症例を経験したの で報告する．症例は 20 歳女性，股関節外転拘縮，屈曲制限が出現したため当院受診となつた．幼少期に 明らかな筋肉注射既往は確認できなかつた。 その後保存療法行うも症状改善無く手術に至つた。手術は内 視鏡を用いた腸脛勒帯切離術を行い術後可動域，跛行は改善した。内視鏡は一般的に関節内など空間での 処置に有用であるが，今回皮下組織下での処置に利用できた。鏡視下の腸脛勒帯切離術は術中股関節の動 態による拘縮の確認が可能で，小皮切で行える有用な手段であると思われた.

We report a case of endoscopic iliotibial band release for contracture of the tensor fasciae latae muscle-iliotibial band. A 20-year-old female consulted our hospital complaining of abduction and flexion contracture of the hip joint.

We could not confirm any history of intramuscular injection in her childhood.

We performed operation after she resisted conservative therapy.

Endoscopic iliotibial band release for the contracture of the tensor fasciae latae muscleiliotibial band improved excursion and claudication.

Use of the endscope is generally good for intra-articular treatments. In this case it was useful for the treatment of hypodermic tissue.

This operation confirms contracture under movement and minimally invasive surgery.

Key words : muscle contracture (筋拘縮症), MIS (低侵襲手術), arthroscopic surgery（関節鏡手 術)

は じめに

筋拘縮症の多くは，筋肉注射による医原性拘縮が多 い. その中で大腿四頭筋が半数以上を占め殿部周囲の 拘縮症は比較的少ないとされている. 今回, 大腿筋膜 張筋から腸脛靭帯にわたる筋拘縮を伴い, 股関節外転 拘縮ならびに屈曲制限に対し，内視鏡を用いた腸脛靭

帯切離術を施行した症例を経験したので報告する.

症例

【症例】 20 歳 女性

【主訴】右股関節屈曲制限, 外転拘縮

【既往歴】3 歳ごろ熱発で入院した既往はあるが筋 肉注射歴含め詳細は不明

\footnotetext{
* 宮崎大学医学部整形外科 Department of Orthopedic Surgery, Faculty of Medicine, University of Miyazaki, Miyazaki, Japan
} 
【現病歴】5 歳ごろから脚長差を自覚していた. 18 歳ごろ歩容異常を指摘されることがあるも放置してい た. 徐々に右股関節の屈曲制限, 外転拘縮が進行し日 常生活動作に支障を来たすようになり当科受診となつ た.

【身体所見】右股関節屈曲 100 度，伸展 0 度，外転 30 度, 内転 -10 度, 内旋 5 度, 外旋 45 度と屈曲 - 内 転・内旋制限を認めた。 右股関節屈曲内転時に体表面 上 tractus cristo-femoris から腸脛勒帯部分に皮膚陥 凹，索状変化を認め，外転により消失した（図 1，2）. 明らかな弾発症状は示さなかった。左側には明らかな 体表面上の異常所見を認めなかつた.

【画像所見】レントゲン正面像にて骨盤傾斜を認め る（図 3）ものの，その他骨性異常等の所見は認めな かった。 全下肢 X 線では下肢全長の左右差を示さな かつた。

MRI では体表面上の皮膚陥凹，索状変化を示す大

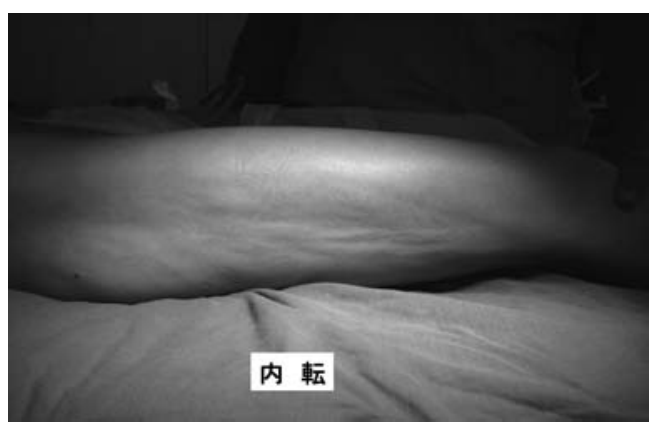

図 1 股関節内転時

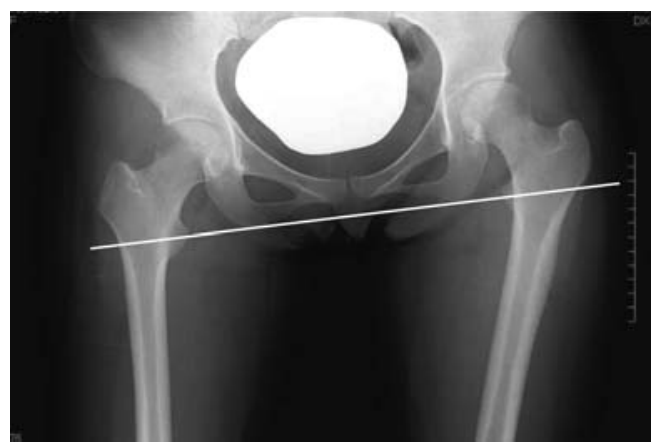

図 3 単純レントゲン両股関節正面像 骨盤傾斜を認める
腿筋膜張筋一腸脛勒带移行部で T1 強調画像にて low intensity を認めた（図 4，5）大殿筋の明らかな筋萎 縮, 索状変化は認めなかった。 筋原性疾患を示唆する 信号変化は認めなかつた。

【治療経過】ストレッチングや温熱療法による保存 的加療を行ったが効果なく手術に至った.

【手術所見】手術は硬膜外＋腰椎麻酔下に左側臥位 で行った. 大転子から上下 $3 \mathrm{~cm}$ の位置にポータルを 2 箇所作成した $(\mathrm{STP}=$ Superior trochanteric portal ITP $=$ Inferior trochanteric portal）（図 6) $40 \mathrm{ml}$ の生理食塩水を大転子上, 腸脛靭帯下に注入し, 腸脛 勒帯下にスペースを形成した。 ITP から $30^{\circ}$ 径 $4 \mathrm{~mm}$ のスコープを挿入し低圧の還流液にて皮下，腸脛勒带 上にスペースを形成した. STPからカメラを挿入し, 大転子直上の腸脛靭帯を露出することでワーキングス ペースを確保した．股関節動態下に腸脛靭帯線維性組 織の緊張を確認し，拘縮の原因となつている部位を特

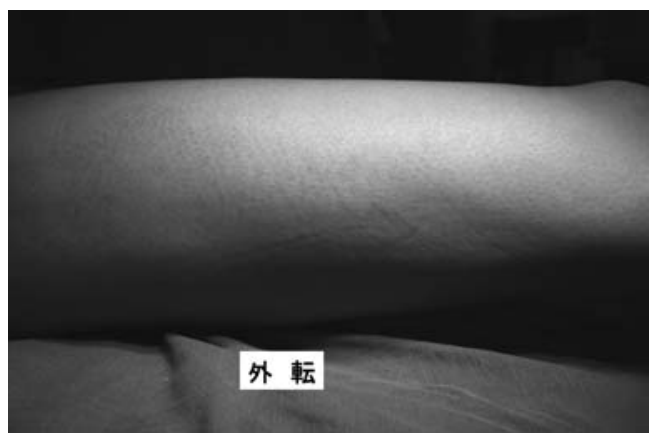

図 2 股関節外転時

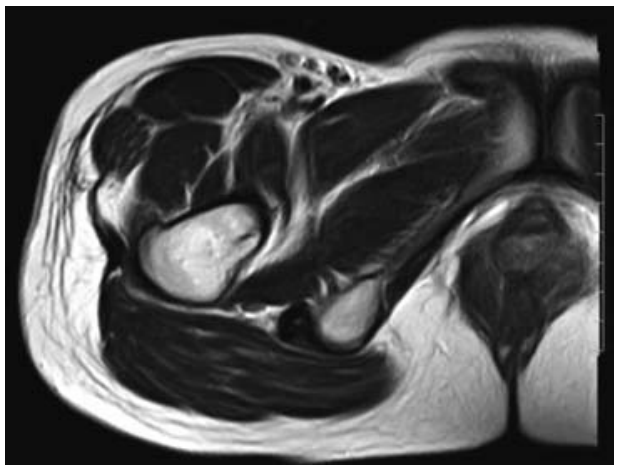

図 4 MRI (T1-WI) 横断像 


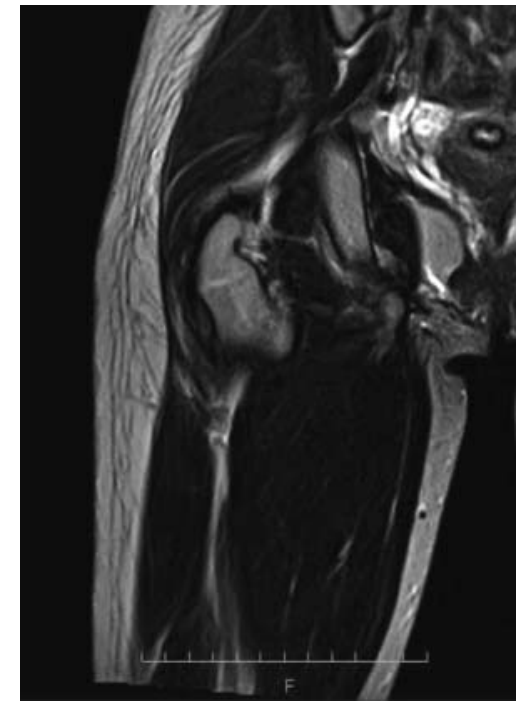

図 5 MRI (T1-WI) 冠状断像

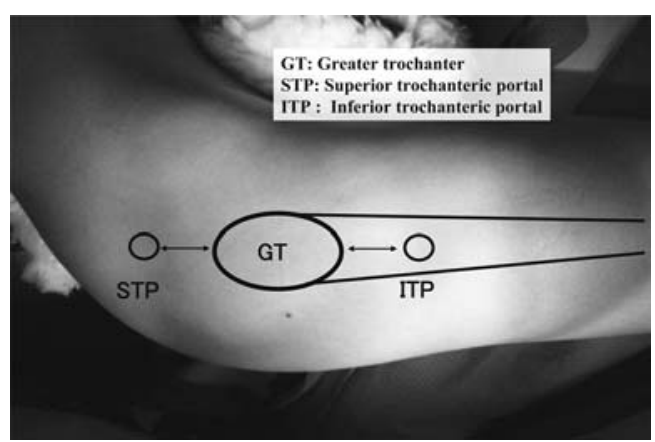

図 62 箇所のポータル

大転子から上下 $3 \mathrm{~cm}$ の位置に作成した $(\mathrm{STP}=$ Superior trochanteric portal ITP=Inferior trochanteric portal)

定した。緊張は内転位にて増加を示したが大転子との 明らかな弾発症状は確認できなかつた。

索状部分の緊張を股関節内転にて確認しながら Radio Frequency を用いて切離を行い, その部分を 中心に弧状に追加切除行った。 今回は大転子弾発症状 示さなかつたため, 腸脛勒帯の完全切離は行わなかつ た. 手術時間は 1 時間 12 分で出血量は少量であった. 術後可動域は右股関節屈曲 120 度, 内転 0 度, 内旋 35 度と改善を認めたが皮膚の索状変化は残存した. 後療法は術翌日より特に制限せず股関節の自動運動お
よび全荷重歩行を許可した.

現在術後 1 年であるが日常生活に支障なく可動域制 限も認めていない.

考

察

筋拘縮症は先天性あるいは後天性に筋肉の疟痕によつ て関節運動が制限される疾患である．股関節拘縮を来 たすものに大腿四等筋拘縮症, 殿筋拘縮症などがある が，大腿四頭筋が殆どを占め，殿筋拘縮は比較的少な いとされている．殿筋拘縮症の中では腸脛勒带に移行 する大殿筋繊維に病変が存在し, 大転子での弾発症状 を示し，関節外型弾発股としての報告が多い. 筋拘縮 症の原因としては筋肉内注射による医原性障害が多く

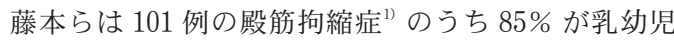
期の殿部への注射の既往があつた ${ }^{2) 4)}$ と報告している. 本症例は筋肉注射の既往がはつきりせず, 大腿筋膜張 筋, 腸脛勒带前方の tractus cristofemoris に限局し た拘縮症であり明らかな弾発症状は来たさなかった （図 7)．筋拘縮症の多くは疼痛を伴わず，弾発症状も しくは可動域制限を認めるのみで, 治療の対象になる ものは少なく, 長期間の保存的治療に抵抗する一部の 症例のみが手術適応となる．手術方法としては腸径勒 帯に対する Z 形成術, 縦切開及び step cut, 棈円切 除などがあり良好な成績が報告されているがこれらの 術式は $10 \mathrm{~cm}$ 以上の皮膚切開を要する事が多い. 近年 転子部周囲の疾患において鏡視下手術の報告が散見さ れ, 鏡視下転子部滑膜切除術, 鏡視下腸径勒帯切離術 などが報告されている.

Victor らは鏡視下腸脛勒帯切離術は従来の術式と 同等の成績であった ${ }^{6)}$ と報告しており，高橋らは鏡視 下腸脛勒带切離術は美容的観点から非常に有用な方法 である5) と報告している.

今回我々は大腿筋膜張筋一腸脛勒帯拘縮に対し内視 鏡を用いた腸脛勒带切離術及び索状物切除を施行した. 本症例では術中視野も良好で腸径勒帯切離及び周囲索 状物切除によって術後可動域は改善することができた. しかし諸家の報告によると鏡視下の処置では良好な視 野確保が困難で切離が不十分となる可能性も示唆され ている．術前に拘縮もしくは弾発の原因部位を正確に 特定することが切離不十分となることを防ぎ，再発の リスクを軽減させるのではないかと示唆される，本術 式は約 $1.5 \mathrm{~cm}$ のポータルを 2 箇所作成するのみで, 


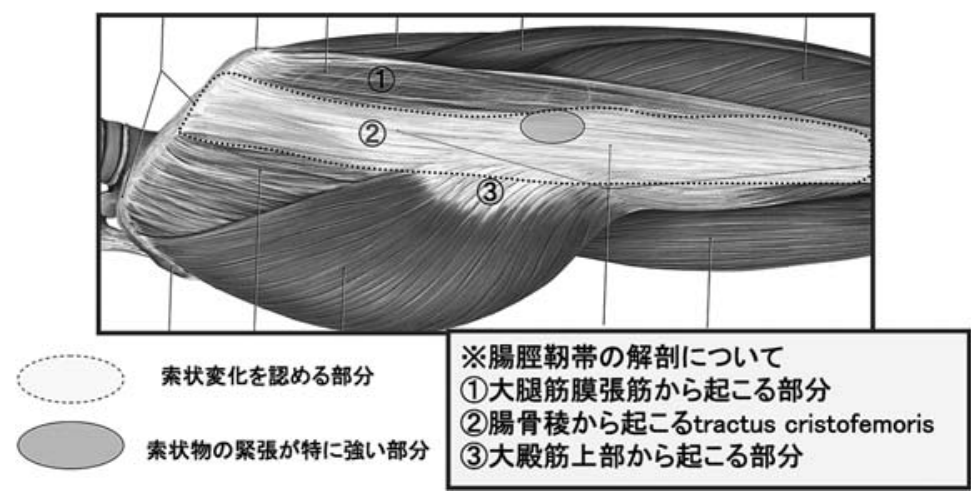

図 7 tractus cristofemorisについて

やはり美容的観点から非常に有用であり特に若い女性 には満足度の高い手術方法であると考えた。

$$
\text { ま と め }
$$

大腿筋膜張筋一腸脛勒帯拘縮に対し内視鏡を用いた 腸脛勒帯切離術を施行した.

本術式は術中視野も比較的良好で動態による原因部 位の特定も可能であり，さらに美容的な観点を含め有 用であると思われた.

今後拘縮の再発を含め慎重な経過観察が必要と思わ れた。
参 考 文 献

1）藤本憲司ほか：筋拘縮症委員会報告（第 3 報）。日整 会誌，52：1458-1459，1978.

2）泉田重雄 : 注射による筋拘縮について。坚臨，25 : 462-469, 1972.

3）森永伊昭：弾発股. NEW MOOK 整形外科, $13: 199$ 208, 2003.

4) 日本整形外科学会筋拘縮症委員会：日本整形外科学会 筋拘縮症委員会報告一筋拘縮症の診断と治療. 日整会誌, $59: 223-253,1985$.

5）高橋詠二ほか：弾発股に対し内視鏡下腸脛勒带切離術 を施行した 1 例. Hip Joint, 35 : 853-856, 2009.

6) Victor, M., et al.: Endscopic Iliotibial Band Release for External Snapping Hip Syndrome. Arthroscopy, $22(5)$ : 505-510, 2006. 